\title{
Gender Does Not Influence Delaying Excuses: An Exploratory Study of the Reasons of Academic Procrastination among College Students
}

\author{
Jasmine $\mathrm{Vij}^{1}{ }^{1}$
}

\section{ABSTRACT}

Gender differences in various psychological constructs are a common phenomenon. This study has been designed to investigate the gender differences if any, in the reasons given for academic procrastination in undergraduate students. For this purpose, 200 high academic procrastinators (113 males and 87 females) in the age group 17-19 years were selected by administering PAAS. The frequency of the reasons given by high procrastinators was calculated by using percentage analysis. Laziness and time management were the two most cited explanations for procrastination. The reasons given by both the genders were compared using chi square. Results revealed that gender does not influence the excuses that males and females provide for academic procrastination.

Keywords: Gender, Gender Differences, Academic Procrastination, Reasons For Procrastination.

Gender refers to the socially constructed roles, behaviors activities and attributes that a given society considers appropriate for men and women. It involves a range of characteristics pertaining to and differentiating between masculinity and femininity. While social sciences in general, and gender studies specifically, consider gender as a social construct, it is an important aspect that males and females have been shown to differ in their psychological characteristics such personality traits (Costa, Terracciano \& McCrae, 2001), risk taking behaviour (Byrnes, Miller \& Schafer, 1999), study habits (Koki \& Abdullahi, 2014) and other such attributes that constitute their behavioral makeup. One such psychological construct to be focused upon in this particular study is procrastination.

Procrastination is a habit involving a tendency to say "I'll do it later". As per the technical definition of procrastination it includes postponing, delaying or putting off a task or a decision.

\footnotetext{
${ }^{1}$ Assistant Professor, Department of Psychology, M. M. Modi College, Patiala, Punjab (India)

*Responding Author

(c) 2016 I J Vij; licensee IJIP. This is an Open Access Research distributed under the terms of the Creative Commons Attribution License (http://creativecommons.org/licenses/by/2.0), which permits unrestricted use, distribution, and reproduction in any Medium, provided the original work is properly cited.
} 


\section{Gender Does Not Influence Delaying Excuses: An Exploratory Study of the Reasons of Academic Procrastination among College Students}

Several writers have mentioned procrastination as a functional delay or as avoiding rush but the dictionary meaning of the verb "procrastinate" is "to postpone, put off, defer, prolong." The origin of the word procrastination lies in two Latin words: 'pro' meaning 'forward' and 'crastinus' which means 'belonging to tomorrow'. Thus, procrastination means to voluntarily delay an intended course of action despite expecting to be worse off for the delay. The essence of procrastination is that the procrastinators delay until the day after tomorrow what they know they should have done the day before yesterday.

Procrastination has been extremely prevalent in the history and has continued to show its effects in the present day scenario. There have been personalities in the past whose behavior can be described as involving the delaying habit. To name a few, Leonardo da Vinci, who created the famous Mona Lisa; Samuel Taylor Coleridge the 18th century poet; Agatha Christie, the best mystery author; and Neville Chamberlain who irrationally put off war with Germany, all procrastinated in their respective fields. Similarly, today procrastination is a widespread phenomenon covering almost all areas of our life. According to Piers Steel, in 1978, only about 5\% of the American public thought of themselves as chronic procrastinators. But with the changing times the data has now increased to $26 \%$ (2007). The change may be attributed to a variety of options available for delaying work, like - TVs in every room, online video, Web-surfing, cell phones, video games, iPods and Blackberries which are perceived as important. At work too one may be distracted by the e-mail, the Internet and games, making procrastination effortless. Moreover, such activities are subjectively considered more fun and are immediately rewarding as opposed to more long-term rewarding activities. The effortful activities are thus delayed.

In this technologically advanced society where time and punctuality should be considered important values, a heavy cost is carried by those who procrastinate. Most of the people assume that the cause of procrastination is laziness but this can have various forms such as procrastination in taking decision with definite time for decision or task aversion (Milgram \& Tenne, 2000). Procrastination may be therefore viewed upon as avoiding the duties and not doing a task by ignoring it (Zimberoff \& Hartman, 2001). It has been reported that time management has been inversely related to procrastinatory behavior (Lay\& Schouwenburg, 1993). As procrastination does reflect an excessive discrepancy between work intentions and work actions and procrastinators tend to have a larger than average intention-action gap (Steel, Brothen \& Wambach, 2001), therefore they suffer psychological stress in their anxious efforts to meet impending deadlines and undergo the pain of failure and criticism for failing to meet deadlines. Thus, procrastination has been considered a specific attribute consisting of cognitive, motivation and behavior components. 


\section{Gender Does Not Influence Delaying Excuses: An Exploratory Study of the Reasons of Academic Procrastination among College Students}

Procrastination has increased in the general population and in particular among students. The present education system gives the students a platform to explore virtual global world where they have many tasks to do in limited time. Academic procrastination includes delaying of academic tasks such as submitting assignments, making projects, depositing fee etc. Such activities are postponed till the deadline approaches. Solomon and Rothblum (1984) have described academic procrastination as postponing primary academic tasks such as preparing for exams, preparing term papers, administrative affairs related to school and duty of attendance. Research has consistently demonstrated that procrastination is one of the biggest threats to academic performance of the students (Moon \& Illingworth, 2005) at each academic level. It has been shown to have an inverse relationship with student's academic performance (Popoola, 2005) leading to lower grades in performances with deadlines (Tuckman, 2002).

Researchers have tried to explore a number of factors that seem to contribute to procrastination habit in students- their motivation level, interest in studies, attitude towards education, personality traits, study habits, home environment etc. An essential point is to emphasize here is that academic procrastination is a form of situational procrastination and has been described as behavior that is linked to a specific task (Harris \& Sutton, 1983). The reasons that are given by the students for their academic procrastination habit gives an insight into the motivation behind delaying or not delaying a task. Thus, self reporting reasons for academic procrastination become the focus of the present study. Here, the foremost step to understand the grounds on which the reasons for the delay are reported becomes to identify various variables associated with academic procrastination.

Certain personality traits are reported to be related to irrational delaying. Schouwenburg \& Lay (1994) sought to trace the sources of trait procrastination by locating it within the five-factor personality structure. The results reveal that trait procrastination was largely associated with lack of conscientiousness. Similarly, a structural equation modeling analyses by Lee et al. (2006) demonstrate that the contentiousness mediator model accounted for $24 \%$ of the variance in trait procrastination. In fact, evidence suggests that procrastination and conscientiousness are aspects of the same construct and are highly inversely correlated (Scher \& Osterman, 2002). Thus, procrastinators who show evidence of low conscientiousness may consider time management as a major reason for their procrastination habit. The effect of locus of control has also been studied on procrastination. It has been shown that students with internal locus of control started working on the assignments, completed and returned them sooner than students with external locus of control. This indicates that internal locus of control leads to less procrastination (Janneson \& Carton, 1999). The students may find themselves dependent on others for their work and thus do not initiate the task. Dependency and indecisiveness may thus become the reason for delay in such situations. 


\section{Gender Does Not Influence Delaying Excuses: An Exploratory Study of the Reasons of Academic Procrastination among College Students}

Another common explanation given for procrastination is evaluation anxiety. Anxiety specifically related to examinations is presumed to have a higher correlation with academic delay (Solomon \& Rothblum, 1984). Also, the tendency to procrastinate on writing tasks is associated with general anxiety, anxiety about writing the paper, writing the paper later than usual, less satisfaction with writing the paper and lower grades (Fritzsche, Young and Hickson, 2003). Task aversiveness has also been reported constantly as a justification for procrastination (Ferrari, Keane, Wolfe \& Beck, 1998; Onwuenbuzie \& Collins, 2001). It has been found that students delayed more on academic tasks labeled unpleasant (Milgram, Marshevsky \& Sadeh, 1995) and tasks regarded as impositions (Milgram, Sroloff \& Rosenbaum, 1988). Thus, rebellion against control also acts as a predictor of procrastination. Burka \&Yuen (2008) have observed that a fragile sense of self-esteem is a personality trait commonly found among procrastinators. Thus, low self-esteem could also be reported as a reason for delaying an academic task.

Considering the issue of gender differences in academic procrastination, researches have shown mixed and inconsistent results. Over a period of time it has been proved consistently that there are no differences in male and female in the delaying behavior. (Howell \& Watson, 2007; Konovalova, 2007; Klassen \& Kuzucu, 2009; Sirin, 2011). Even in the Asian countries such as India (Sharma \& Kaur, 2011) and Pakistan (Saleem \& Rafique, 2012) no gender difference in procrastination was found. However Senecal, Koestner, and Vallerand (1995) stated in their research that women have generally been reported as being more intrinsically motivated and less externally regulated and amotivated with regard to academic activities as compared to men. Therefore, males procrastinate more than females on academic tasks. Similarly, Klassen et al (2009), Yong (2010) and Pala, et al (2011) have demonstrated males tend to procrastinate more than females.

Although a gender difference in tendency to procrastinate has been extensively researched, there seems to have been limited research on the reasons that are given for the delaying habit. Konovalova (2007) in a research paper indicated that there were no gender differences in the reasons for procrastination between men and women. However Özer, Demir \& Ferrari (2009) specified that significantly more female students than male students reported greater academic procrastination because of fear of failure and laziness. Also, male students reported more academic procrastination as a result of risk taking and rebellion against control than did female students. A gender difference has also been found in the fear of success as a trait (Horner, 1968). Females generally believe that their successful performance would have negative consequences such as unpopularity and a reduced feeling of femininity because they view success as counter to their roles in our culture and are therefore afraid of it. But because of inadequate number of studies to prove the point and to stress upon the fact that there are gender differences in many other psychological attributes and habits, it was assumed that there might be a variation in how males and females interpret, analyze and justify a delaying act. Moreover, as differences in males and females have been reported in India with respect to socialization (Ram, Strohschein \& Gaur, 


\section{Gender Does Not Influence Delaying Excuses: An Exploratory Study of the Reasons of Academic Procrastination among College Students}

2014) and personality traits (Magan et al., 2014) there might also be gender differences in excuses for the delaying habit. Focusing on the above mentioned points the purpose of the present paper thus, is to evaluate the reasons given for procrastination and to analyze the gender differences, if any among male and female high procrastinators in their reasons for procrastination.

\section{METHODOLOGY}

\section{Sample}

The data was collected on the principle of simple random sampling. 200 high academic procrastinators were selected for the study out of the general population of students. Out of the total sample of high academic procrastinators, 113 were males and 87 were females. They were all in the age group of 17-19 years $(\mathrm{M}=18.89, \mathrm{SD}=0.54)$ and were studying in technical colleges in undergraduate courses.

\section{Test used}

Procrastination Assessment Scale-Students (PASS) was used to assess student's procrastination tendency in academic tasks. It has 44-items using 5-point Likert Scale. This scale is developed by L. J. Solomon and E. D. Rothblum (1984). The scale is divided into two parts; the first part measures the prevalence of procrastination in six academic areas and the second part assesses the reasons for procrastination. For the first part- Areas of Procrastination, the instructions were, "For each of the following activities, please rate the degree to which you delay or procrastinate. Rate each item on an "a" to "e" scale according to how often you wait until the last minute to do the activity. Then indicate on an "a" to " $\mathrm{e}$ " scale the degree to which you feel procrastination on that task is a problem. Finally, indicate on an "a" to "e" scale the degree to which you would like to decrease your tendency to procrastinate on each task." For the second part- Reasons for Procrastination, the instructions were, "Think of the last time the following situation occurred. It's near the end of the semester. The term paper you were assigned at the beginning of the semester is due very soon. You have not begun work on this paper. There are reasons why you have been procrastinating on this task. Write 'yes' or 'no' against each statement indicating whether or not it was the reason for your procrastination in this situation." There were 13 reasons considered in this test having two statements for each reason. The reasons include; laziness, time management, indecisiveness, peer pressure, dependency, task aversiveness, risk taking, perfectionism, lack of assertiveness, evaluation anxiety, low selfesteem, rebellion against control and fear of success. The scoring of the test was done manually.

\section{Procedure}

The objective of this paper was to evaluate the reasons given for procrastination and to analyze the gender differences in reasons for procrastination. For this purpose, 600 participants were selected by the procedure of simple random sampling. They were tested in twelve groups of 50 each. The participants were seated in the classroom and were explained the meaning of procrastination. Then they were given the PASS test with proper instructions for performance. After the scoring, 200 extremely high procrastinators (133 males and 87 females) were selected 


\section{Gender Does Not Influence Delaying Excuses: An Exploratory Study of the Reasons of Academic Procrastination among College Students}

from the participants. The reasons given by them were analyzed and the gender differences in the reasons were compared with the use of chi-square.

\section{RESULT \& DISCUSSION}

For the present research percentage analysis and chi-square test was used to analyze the difference between males and females in their selection of reasons on their habit of procrastination. The statistical results are shown in Tables 1 and 2. Table 1 indicates that laziness (40\%) is the most cited reasons for procrastination in academic tasks. Laziness has been persistently considered as a major factor of not letting the task started (Yong, 2010; Özer, Demir \& Ferrari, 2009). According to the factor analyses of the reasons of procrastination by Solomon and Rothblum (1984), the second factor which accounted for $18 \%$ of the variance relates to laziness and task evasiveness. Laziness has been consistently been reported to have adverse consequences for an individual, be it academic, day to day activities, health issues and the like. In the present time, one has a number of distractions readily available such as variety of T.V. channels, video games, surfing the net, vast range of online games and shopping, chatting online with friends and sometimes mere checking of other people's status and posts on social networking sites. The diversions make a person glued to it as it is entertaining and does not require effort. It automatically poses a hindrance to initiate any kind of activity with determination as it acts as an escape to a relaxing and enjoyable world. The hectic life threatens the individuals' indulgence into a pleasure oriented tasks and thus whenever one feels a little exhausted, he pampers himself by not doing anything and just being lazy.

Table 1, Summary table for the frequency and percentage of reasons of academic procrastination in descending order

\begin{tabular}{|c|c|c|c|c|}
\hline \multirow{2}{*}{$\begin{array}{l}\text { Rank } \\
1\end{array}$} & \multirow{2}{*}{$\begin{array}{l}\text { Reasons } \\
\text { Laziness }\end{array}$} & \multirow{2}{*}{\begin{tabular}{cc}
\multicolumn{3}{|c}{ Responses $(\mathbf{N}=300)$} \\
No Yes
\end{tabular}} & \multicolumn{2}{|c|}{$\begin{array}{l}\text { Percentage of subjects } \\
\text { saying yes }\end{array}$} \\
\hline & & & 80 & 40 \\
\hline 2 & Time management & 130 & 75 & 37.5 \\
\hline 3 & Indecisiveness & 134 & 66 & 33 \\
\hline 4 & Peer pressure & 141 & 62 & 31 \\
\hline 5 & Dependency & 145 & 55 & 27.5 \\
\hline 6 & Task aversiveness & 148 & 52 & 24.5 \\
\hline 7 & Risk taking & 170 & 40 & 20 \\
\hline 8 & Perfectionism & 170 & 40 & 20 \\
\hline 9 & Lack of assertiveness & 172 & 38 & 19 \\
\hline 10 & Evaluation anxiety & 178 & 32 & 16 \\
\hline 11 & Low self- esteem & 180 & 30 & 15 \\
\hline 12 & Rebellion against control & 182 & 28 & 14 \\
\hline 13 & Fear of success & 186 & 20 & 10 \\
\hline
\end{tabular}




\section{Gender Does Not Influence Delaying Excuses: An Exploratory Study of the Reasons of Academic Procrastination among College Students}

Time management was scored the second most cited reason with $37.5 \%$ of the students reporting to delay the task because they were unable to manage time. This indicates that high procrastinators are unable to organize their time, they feel overwhelmed by work assigned to them and cannot prioritize the tasks at hand. Lay and Schouwenburg (1993) examined the relation of time management and procrastination where time management was conceptualized in terms of goals and priorities, the use of mechanics and the perceived control of time and found time management was inversely related to the delaying behavior. High procrastinators have difficulty getting anything done because they are constantly switching from one task to another or trying to decide what to do next. All these factors pose a hindrance in starting to work for a task and thus lead to procrastination.

The next prominent reason for procrastination in students was indecisiveness (33\%). It was found to be one of the reasons in a study by Yong (2010). Such individuals are unable to decide what to do about the task at hand and also how to do it. They have various options but are unable to choose among them or simply spend too much time trying to decide which results in the delay. Peer pressure (31\%) is the next reason to be cited by high academic procrastinators. Peer pressure seems to be influencing the young adults in on various dimensions. It is the influence of friends or groups to which a student wants to be a part. In order to get their approval or please them, an individual feels pressurized to do what others have induldged into. A procrastinator may not initiate a task realizing that his counterparts also have not started it as yet. Dependency is the next cited reason for academic procrastination with $27.5 \%$ of the students reporting to be dependent on others in academic tasks for assistance or help in some way. Some may be waiting for instructions from the teacher or for others to do their work so that they can take some guidance or ideas from it. The dependency factor does not let them start the task on their own and thus result in procrastination.

Although, task aversiveness has been consistently found to be an important factor contributing to academic procrastination (Solomon and Rothblum, 1984; Lay, 1992; Clark and Hill, 1994; Onwuenbuzie \& Collins, 2001), in the present findings it came out to be the sixth most cited reason with $26 \%$ of the high procrastinators delaying because of their disliking for the task.

The least cited reason by high academic procrastinators for their delaying habit was fear of success $(10 \%)$. It indicates that only a small number of high procrastinators feel that their punctuality would be not be appreciated and they would be disliked by other students for doing the work in time. Also they might be apprehensive that the success that comes with the regularity of work would lead to better expectations for future.

Although gender differences in the prevalence of academic procrastination have been widely reported (Pala et al, 2011; Sirin 2011), studies describing the gender difference in the reasons given for procrastination by male and female student are not extensive. As reported, female and 


\section{Gender Does Not Influence Delaying Excuses: An Exploratory Study of the Reasons of Academic Procrastination among College Students}

male students provide different explanations for the academic delaying habit (Özer, Demir \& Ferrari, 2009). However, Konovalova (2007) reported that no gender difference in the reasons for procrastination was found. The chi-square analysis in the present study also provides a similar finding. As seen in Table 2 high academic procrastinators do not differ in any of the thirteen reasons given for procrastination on the basis of their gender.

Table 2, Showing the chi-square result of males and females in relation to reasons for academic procrastination

\begin{tabular}{llc}
\hline S.No. & Reasons & Chi-square $\left(\mathbf{X}^{\mathbf{2}}\right)$ \\
\hline 1 & Laziness & $1.315 \mathrm{~ns}$ \\
2 & Time management & $0.001 \mathrm{~ns}$ \\
3 & Indecisiveness & $0.480 \mathrm{~ns}$ \\
4 & Peer pressure & $0.000 \mathrm{~ns}$ \\
5 & Dependency & $1.098 \mathrm{~ns}$ \\
6 & Task aversiveness & $0.931 \mathrm{~ns}$ \\
7 & Risk taking & $0.154 \mathrm{~ns}$ \\
8 & Perfectionism & $0.004 \mathrm{~ns}$ \\
9 & Lack of assertiveness & $0.008 \mathrm{~ns}$ \\
10 & Evaluation anxiety & $0.001 \mathrm{~ns}$ \\
11 & Low self- esteem & $0.020 \mathrm{~ns}$ \\
12 & Rebellion against control & $1.061 \mathrm{~ns}$ \\
13 & Fear of success & $2.136 \mathrm{~ns}$
\end{tabular}

Summarizing the findings of the present study, it can be said that although males and females differ in many attributes and habits but their thought process does not vary while providing excuses for delay in academic tasks.

\section{REFERENCES}

Burka, J. B. \& Yuen, L. M. (2008). Procrastination. Why You Do It, What To Do About It Now. MA: Da Capo Press.

Byrnes, J. P., Miller, D. C., \& Schafer, W. D. (1999). Gender differences in risk taking: A metaanalysis. Psychological Bulletin, 125(3), 367-383.

Clark, J. L. \& Hill, O. W. (1994). Academic Procrastination among African-American college students. Psychological reports, 75(2), 931-936. 


\section{Gender Does Not Influence Delaying Excuses: An Exploratory Study of the Reasons of Academic Procrastination among College Students}

Costa, P. Jr., Terracciano, A., \& McCrae, R. R. (2001). "Gender differences in personality traits across cultures: Robust and surprising findings". Journal of Personality and Social Psychology, 81(2), 322-31.

Ferrari, J. R., Keane, S. M., Wolfe, R. N., \& Beck, B. L. (1998). The Antecedents and Consequences of Academic Excuse-Making: Examining individual differences in procrastination. Research in Higher Education, 39(2), 199-215.

Fritzsche, B. A., Young, B. R., \& Hickson, K. C. (2003). Individual differences in academic procrastination tendency and writing success. Personality and Individual differences, 35(7), 1549-1557.

Harris, N. N., \& Sutton, R. I. (1983). Task procrastination in organizations: A framework for research. Human Relations, 36, 987-996.

Horner, M. S. (1968). Sex differences in achievement motivation and performance in competitive and noncompetitive situations. Unpublished doctoral dissertation, University of Michigan, Ann Arbor.

Howell, A. J. \& Watson, D. C. (2007). Procrastination: Associations with achievement goal orientation and learning strategies. Personality and Individual Differences, 43, 167-178.

Janneson, T. \& Carton, J. S.(1999). The effects of locus of control and task difficulty on procrastination. The Journal of Genetic Psychology, 160(4), 436-442.

Klassen, R. \& Kuzucu, E. (2009). Academic Procrastination and Motivation of adolescents in Turkey. Educational Psychology, 29(1), 69-81.

Klassen, R. M., Ang, R. P., Chong, W. H., Krawchuk, L. L., Huan, V. S., Wong, I. Y. F., \& Yeo, L. S. (2009). A Cross-Cultural Study OF Adolescent Procrastination. Journal of Research on Adolescence, 19(4), 799-811.

Koki, A. T. A \& Abdullahi, U.(2014). Gender differences in study habit skills of undergraduate students of Yobe State University, Damaturu, Yobe State, Nigeria. Knowledge Review, 31(2).

Konovalova, L. (2007). Gender and Age Differences in Academic Procrastination, Task Aversiveness, and Fear of Failure. Paper presented at the $87^{\text {th }}$ Annual Western Psychological Association Convention, May 3-6, 2007, in Vancouver, Canada.

Lay, C. H. \& Schouwenburg, H. C. (1993). Trait procrastination, time management and academic behavior. Journal of Social Behavior \& Personality, 8(4), 647-662.

Lay, C. H. (1992). Trait procrastination and the perception of person-task characteristics. Journal of Social Behavior and Personality, 7(3), 483-494.

Lee, D., Kelly, K. R., \& Edwards, J. K. (2006). A closer look at the relationships among trait procrastination, neuroticism, and conscientiousness. Personality and Individual Differences, 40(1), 27-37.

Magan, D., Mehta, M., Sarvottam, K., Yadav, R. K., \& Pandey, R. M. (2014). Age and gender might influence big five factors of personality : a preliminary report in Indian population. Indian Journal of Physiology Pharmacology, 58(4), 381-388. 


\section{Gender Does Not Influence Delaying Excuses: An Exploratory Study of the Reasons of Academic Procrastination among College Students}

Milgram, N. A. \& Tenne, R. (2000). Personality correlates of decisional and task avoidant procrastination. European Journal of Personality, 14, 141.

Milgram, N. A., Marshevsky, S. \& Sadeh, C. (1995). Correlates of academic procrastination: Discomfort, task aversiveness and task capability. The Journal of Psychology, 129(2), 145-155.

Milgram, N. A., Sroloff, B., \& Rosenbaum, M. (1988). The procrastination of everyday life. Journal of Research in Personality, 22(2), 197-212.

Moon, S. M. \& Illingworth, A. J. (2005). Exploring the dynamic nature of procrastination: A latent growth curve analysis of academic procrastination. Personality and Individual Difference, 38(2), 297-309.

Onwuenbuzie, A. J. \& Collins, K. M. (2001). Writing apprehension and academic procrastination among graduate students. Perceptual and motor skills, 92(2), 560-562.

Özer, B. U. Demir, A. \& Ferrari, J. R. (2009). Exploring Academic Procrastination Among Turkish Students: Possible Gender Differences in Prevalence and Reasons. The Journal of Social Psychology, 149(2), 241-257.

Pala, A., Akyildiz, M. \& Bagci, C. (2011). Academic Procrastination Behaviour of Pre-service Teachers of Celal Bayar University. Procedia- Social and Behavioral Sciences, 29, 1418-1425.

Popoola, B. I. (2005). A Study of Procrastinatory Behaviour and Academic Performance of Undergraduate Students in South Western Nigeria. Journal of Social Science, 11(3), 215218.

Ram, U., Strohschein, L., \& Gaur, K. (2014). Gender Socialization: Differences between Male and Female Youth in India and Associations with Mental Health. International Journal of Population Research, 2014. http://dx.doi.org/10.1155/2014/357145

Saleem, M. \& Rafique, R. (2012). Procrastination and Self-Esteem among University Students. Pakistan. Journal of Social and Clinical Psychology, 10(2), 50-53.

Scher, S. J. \& Osterman, N. M. (2002). Procrastination, contentiousness, anxiety and goals: Exploring the measurement and correlates of procrastination among school-aged children. Psychology in the Schools, 39(4), 385-398.

Schouwenberg, H. C. \& Lay, C. H. (1995). Trait Procrastination and the Big Five Factors of Personality. Personality and Individual Differences, 18(4), 481-490.

Senecal, C., Koestner, R., \& Vallerand, R. J. (1995). Self Regulation and Academic Procrastination. The Journal of Social Psychology, 135(5), 607-619.

Sharma, M. \& Kaur, G. (2011). Gender differences in Procrastination and Academic Stress among adolescents. Indian Journal of Social Science Researches, 8(1-2), 122-127.

Sirin, E. F. (2011). Academic procrastination among undergraduates attending school of physical education and sports: Role of general procrastination, academic motivation and academic self-efficacy. Educational Research and Reviews, 6(5), 447-455.

Solomon, L. J., Rothblum, E. D. (1984). Academic Procrastination: Frequency and Cognitivebehavioural correlates. Journal of Counselling Psychology, 31(4), 503-509. 


\section{Gender Does Not Influence Delaying Excuses: An Exploratory Study of the Reasons of Academic Procrastination among College Students}

Steel, P. (2007). The Nature of Procrastination. A Meta-Analytic and Theoretical Review of Self Regulatory Failure. Psychological Bulletin, 133(1), 65-94.

Steel, P., Brothen, T. \& Wambach, C. (2001). Procrastination and Personality, Performance \& Mood. Personality and individual differences, 30(2), 95-106.

Tuckman, B. W. (2002). Academic Procrastinators: Their Rationalizations and Web-course performance. Paper presented at the American Psychological Association, Chicago.

Yong, F. L. (2010). A Study on the Assertiveness and Academic Procrastination of English and Communication Students at a Private University. American Journal of Scientific Research, 9, 62-72.

Zimberoff, D. \& Hartman, D. (2001). Four Primary Existential Themes In Heart-Centered Therapies. Journal of Heart-Centered Therapies, 4(2), 15. 